\title{
Development of primary health care in Ukraine in the light of global trends
}

\author{
Valeriia M. Lekhan', Henadiy O. Slabkyy², Valentina H. Ginsburg³ , Liliia V. Kryachkova', \\ Marina V. Shevchenko \\ ${ }^{1}$ Dnipropetrovsk Medical Academy \\ ${ }^{2}$ State Administration Ukrainian Institute of Strategic Research of the Ministry of Public Health of Ukraine \\ ${ }^{3}$ Main Healthcare Department of Dnipropetrovsk Regional State Administration \\ Lekhan VM, Slabkyy HO, Ginsburg VH, Kryachkova LV, Shevchenko MV. Development of primary health care in Ukraine in the light of global \\ trends. Med Og Nauk Zdr. 2015; 21(2): 193-197. doi: 10.5604/20834543.1152919
}

\section{Abstract with international factual standards. on the use of actual data and its context, has been defined. \\ Key words \\ primary health care, model, components, modernization}

Introduction and objective. In the article various approaches, principles and requirements as to the organization of the primary health care (PHC) are analyzed, the efficiency of which has been proved in well-planned international studies. The aim of the study is to assess the compliance of the approaches for the renovation of the system of PHC provision in Ukraine

Material and methods. The comparative characteristics of the PHC organization in different countries of Europe have been conducted. It has been proved that the model of modernization of healthcare in Ukraine fully corresponds to the principles, requirements and criteria that were created for the effective functioning of $\mathrm{PHC}$ worldwide.

Results. The complex of measures relating to the implementation of the model of PHC modernization in Ukraine, based

\section{INTRODUCTION}

Primary health care (PHC) is the sphere of the first contact of the patient with the system of healthcare.

It has been scientifically proved nowadays that a wellorganized PHC influences the health of the population much better than specialized and highly specialized care. The results of international studies point out the positive connection between the development of PHC in the country and the health of the population (i.e. the level of general mortality and premature mortality, coronary disease mortality and cancer mortality, neonatal mortality and the expected life span of the population) $[6 ; 13 ; 14]$.

Besides, it has been demonstrated that ensuring a greater accessibility of PHC decreases general inequality in receiving medical aid. At the same time, the countries in which healthcare systems are dominated by specialists show higher general mortality rates and lower access of the most vulnerable population groups to the healthcare services. What is more, the international community as a whole, as well as the World Health Organization (WHO), considers it absolutely unacceptable for the PHC to be used as a synonym for low-tech, unprofessional aid meant for the country's residents and low-income groups, who cannot afford higher quality aid [1].

Objective. To assess the compliance of the approaches for the renovation of the system of PHC provision in Ukraine with international factual standards.

Adres do korespondencji: Adres do korespondencji:Valeriia Lekhan, Dnipropetrovsk Medical Academy, Dnipropetrovsk, K. Marx Avenue, 24

E-mail:v.n.lexan@gmail.com

Nadesłano: 30 kwietnia 2014; zaakceptowano do druku: 06 lutego 2015

\section{MATERIALS AND METHOD}

This study analyzes the approaches, principles and requirements for the PHC organization, the efficiency of which has been proved in some well-planned international studies. A complex of measures relating to the implementation of the model of PHC modernization in Ukraine, based on the use of actual data and its context, has been defined.

\section{RESULTS AND DISCUSSION}

The Strategy of PHC presented in the report for the World Health Organization (WHO) in 2008 'Primary health care. More topical today than ever' [10] contained the following principles:

- the institution which provides PHC is the place where people with a wide range of health problems, and not only a limited group of some 'priority illnesses' can come;

- A PHC institution is the centre from which patients are sent to various services of the healthcare system when there is a need for this;

- PHC facilitates the establishment of permanent contacts between patients and general practitioners, within the frameworks of which patients take part in the process of making decisions which relate to their health and medical help; it provides an opportunity to 'build bridges' between individual medical servicing, and not only the patients' families, but also the societies to which they belong;

- PHC is not limited by treatment only of the most widespread illnesses, it opens up possibilities for preventing diseases, propagandizing a healthy lifestyle and early disease diagnosis;

- medical teams (doctors, nurses and experts with special and modern training in the sphere of social work) are needed for rendering the $\mathrm{PHC}$; 
- PHC should be provided with proper resources; only in this case can it guarantee a better correlation of price and quality than alternative approaches.

The main principles of the effective PHC organization at the present stage include [9]:

- putting the interests of people at the centre of PHC services;

- the right to achieve the maximum possible level of health;

- providing a maximum level of equality and solidarity;

- consideration of people's needs.

Adherence to the above-mentioned principles demands correspondence of PHC to international criteria:

- orientation towards a patient (Tab. 1,2);

- a comprehensive character (help for everybody, regardless of age, gender, social status, race or religion; consideration of every complaint or medical problem of any character);

- availability (free access to the services of PHC with a minimum term of waiting);

- integration (diagnostics, treatment, health resumption, strengthening of health, and prophylaxis of diseases);

- a continuous character (help, which is not limited by a separate case or any disease; providing the patient with individual health care on a long-term basis during the patient's life);

- integrity (consideration of the medical problems of a person, a family and the society in the plan of physical, psychological and social prospects);

- a personal character (oriented to personality, and only then on a disease; support based on mutual relations between patient and doctor);

- direction to the family (a study of the problems in the context of a family and social contacts of a person);

- direction to the contingent that is served (consideration of the problems of patients in the context of their life in local conditions);

- coordination (referral of patients, medical problems that go beyond PHC, to doctors or specialists, or to in-patient departments, and receipt of the information about the results of the conducted consultations or interferences);

- a confidence character (observance of confidentiality of the information about the health of a patient);

- an advocacy function (the primary care physician acts as a patient's advocate in all matters relating to health, before other medical care providers).

To achieve the main goal facing $\mathrm{PHC}$ - providing an acceptable level of health, the following health care systems 'putting people's interests in the spotlight of health care services' are necessary. Of particular importance is the 'focus on the patient', which promotes a substantial increase in the quality of medical care, treatment success, and quality of life of the medical care consumers (Tab. 1, 2). However, according to the WHO definition, health care systems unreasonably pay too much attention to providing highly specialized medical care. At the same time, it is much more difficult to cope with health problems because the patient should be understood holistically, taking into account his/ her physical, emotional and social status, past and future, as well as the realities of the world he/she lives in. Ignoring specific family and social context in which the individual lives and acts, leads to overlooking important components of his/her health state, which do not necessarily correspond to any category of disease. For example, medical care services which work in quite close cooperation with communities and health workers who know the local people well are able to detect, prevent or mitigate the effects of conditions that can eventually develop into serious illnesses. People must be sure that the doctor understands their suffering and difficulties. However, in many medical establishments a sympathetic attitude and focus on the patient are regarded as luxuries which are available only to the elite. According to numerous data, focus on the patient is important not only in terms of lessening patient anxiety or increasing health workers' satisfaction with their work; solving a health problem will be more effective if the health care provider sees this problem from all its aspects.

Table 1. Peculiarities distinguishing traditional health care from primary health care, which is orientated to a patient [9]

\begin{tabular}{ll}
\hline $\begin{array}{l}\text { Traditional ambulatory care in } \\
\text { polyclinics or polyclinic departments }\end{array}$ & $\begin{array}{l}\text { Primary health care orientated to } \\
\text { a patient }\end{array}$ \\
\hline $\begin{array}{l}\text { Prior attention paid to the disease and } \\
\text { its treatment }\end{array}$ & $\begin{array}{l}\text { Prior attention paid to the patient's } \\
\text { needs in the sphere of healthcare and } \\
\text { medical help }\end{array}$ \\
\hline $\begin{array}{l}\text { Interaction limited by the moment of } \\
\text { consultation }\end{array}$ & Long-lasting personal relationship \\
\hline Occasional medical help & $\begin{array}{l}\text { Universal non-stop help orientated to } \\
\text { the patient }\end{array}$ \\
\hline $\begin{array}{l}\text { Responsibility limited to giving } \\
\text { a patient an effective and safe piece of }\end{array}$ & $\begin{array}{l}\text { Responsibility for the state of health of } \\
\text { all the members of the society during } \\
\text { the whole life cycle; responsibility for } \\
\text { struggling against the factors that } \\
\text { have a negative influence on health }\end{array}$ \\
\hline People are consumers of services & $\begin{array}{l}\text { People are partners, they take part in } \\
\text { solving the matters of their own health } \\
\text { and the health of society }\end{array}$ \\
\hline
\end{tabular}

Table 2. Orientation to a patient: improvement of quality and effectiveness of help [9]

Orientation to a patient

Improvement of treatment intensity and life quality

Deeper understanding of psychological aspects of the patient's problems

Higher satisfaction with the results of communication

High level of patient's confidence in matters not related to health

Higher level of confidence and readiness to maintain a regime of treatment

Wider introduction of aspects relating to prevention and propagandization of

a healthy lifestyle into the therapy

For the majority of countries, $\mathrm{PHC}$ remains the guideline in policy-making in the sphere of health care due to the movement for its support offering rational, scientific and advanced solutions of a problem of people's needs satisfaction in the sphere of health care and people's social expectations. According to the experience of the most successful, from the point of view of health care, countries, (Tab. 3) PHC should: - be separated from secondary care;

- be close to inhabitancy, which is provided by means of a ramified network of outpatient departments or private practices (preferably this practice is a group one, in which several primary care doctors work together); besides, management functions can be relied upon in PHC centres, i.e. trust; 
- have a decentralized nature which reduces queues and the possibility of becoming infected while in the establishment;

- be suitable for getting medical help (operating schedule / reception schedule should be formed on the basis of studying demand at different time of the day and days of the week);

- be given by general practitioners / family doctors; in case they are not enough it should be given by physicians and pediatricians;

- perform a controlling-and-accessing function (appointment card to specialists and hospitals should be given in non-'acute' states) for forming the right route for the patient, decreasing the possibility of unnecessary intervention which can be accompanied by negative consequences for health;

- provide patients' participation in the process of rendering medical help through the mechanism of the patient's free choice of primary care physician;

- motivate medical staff for intensive and quality work through using corresponding mechanisms of PHC financing (according to the poll principle).

In Ukraine, the model of PHC, which was formed in the period of 1920s-1930s under the pressure of objective circumstances of those times - the economic crisis in the country against the background of the epidemics of some infectious diseases (typhus, tuberculosis, trachoma, syphilis, etc.) has been valid until now. Special medical structures (pediatric clinics, antenatal clinics, dispensaries, medical rooms) were created to solve the problems of prior medical servicing (fighting against infectious diseases, rendering help to certain groups of people (children, women, workers), while other populations receive help on the 'leftover' principle. In those years, perhaps it was the only possible way to concentrate extremely limited resources on the main tasks. Afterwards, the economic and epidemiology situation changed, but structures created remained. Because of this, there exist a number of negative characteristics of the national model of PHC:

- the structural break-up of PHC, represented by numerous establishments (adult outpatient department and paediatric clinics, maternity welfare clinics, etc.) which function isolated from one another, the mechanisms of their co-operation are not yet devolved, which results in the violation of major principles of medical service - continuity and complexity of medical process;

- excessive participation in providing PHC with doctors-specialists, which results in the depersonalization of medical care, disqualification of medical personnel, and ineffective charges for limited resources;

- the absence of effective mechanisms of responsibility (economic, moral, legal) for the patient's life and state of health.

For the past two decades, all countries, including those which had more successful systems of PHC, onducted reforms of the systems of health care, on the assumption of a necessity to provide a greater correspondence to the vital requirements of the population in a health care, and to increase their influence on the health of population. Ukraine is one of the few countries where the system of PHC practically did not change, in spite of the radical changes in the country's situation, including the socio-economic structure. This resulted in one of the worst indexes of health of a population in Europe (high death rate, short life span), and an extremely insufficient influence of the system of health care on these indexes. According to the data of the World bank, through an $80 \%$ decrease among the men of capable working age and a $30 \%$ deceases among the women of capable working age, it was possible to prevent this by means of the proper treatment at PHC level [2]. Only from the year 2010, after acceptance by the president of Ukraine of the programme of economic reforms, that there began in 2010-2014 under a 'rich society, competitive economy and effective state', the transformation in the system of health care.

The model of modernization of the health care in Ukraine fully corresponds to the principles, requirements and criteria created for the effective functioning of $\mathrm{PHC}$ worldwide, and includes the following components:

- the legal and structural differentiation of PHC and secondary health care;

- formation of the ramified and properly equipped infrastructure of $\mathrm{PCH}$;

- the input of the PHC system on the family principle;

- the input of the 'gating' system (principle of the 'goalkeeper') to form the optimal route of a patient;

- the input of a patient's free choice of a doctor of primary link;

- financing of the PHC establishments from municipal and district budgets on the poll principle;

- payment of the work of the medical personnel of the primary link, on the basis of the scope and quality of the work undertaken.

Nowadays, the complex measures for its realization have beenfulfilled, first of all, in pilot regions:

- legal differentiation of PHC and secondary help is performed, which will not allow distraction of the resources intended for strengthening PMSH to other types of services; - work on building infrastructure - a network of out-patients' clinics which are as close to the residence of patients as possible - carried out with limited resources that make it difficult (especially in cities) to create a network of independent out-patients' clinics; it is planned to decentralize them in order to provide a separate entrance, reception, a laboratory or premises for the collection of biological material (blood, urine), with their delivery carried out by the medical personnel of an out-patients' clinic to the laboratory of the institution that provides specialized medical care;

- opening hours of out-patients' clinics and doctors' working hours are defined, which provides the most convenient surgery hours (morning and evening, weekends, etc.), and minimal crossing of streams of special contingent patients (assigning days and surgery hours for children, pregnant women, dispensary group patients, etc.);

- out-patients' clinics are staffed with family physicians, and when there is a lack of them - with therapeutists, paediatricians, obstetrician-gynecologists;

- funds for planned re-equipment of out-patients' clinics and centres of PHC are allocated in accordance with the functions they perform;

- registration of the population which is served by each centre of PHC care is undertaken (on the basis of a real population census); 
Table 3. Comparative characteristics of primary health care (PHC) in different countries

\begin{tabular}{|c|c|c|c|c|c|c|}
\hline Country & $\begin{array}{l}\text { Specialists who } \\
\text { render PHC }\end{array}$ & Structures of PHC & $\begin{array}{l}\text { Access to specialists and } \\
\text { hospitals }\end{array}$ & PHC Structures fee & $\begin{array}{l}\text { Mothers' and children } \\
\text { care }\end{array}$ & $\begin{array}{l}\text { Scheme of forming } \\
\text { of contingent under } \\
\text { the care of primary } \\
\text { link specialists }\end{array}$ \\
\hline $\begin{array}{l}\text { Poland } \\
{[9]}\end{array}$ & $\begin{array}{l}\text { General practitioners; } \\
\text { the lack thereof } \\
\text { - physicians and } \\
\text { paediatricians }\end{array}$ & $\begin{array}{l}\text { Private practice (dominating } \\
\text { structure); clinics; } \\
\text { outpatients> clinics }\end{array}$ & $\begin{array}{l}\text { Under primary link doctors' } \\
\text { referral ('goalkeeper' } \\
\text { principle) }\end{array}$ & $\begin{array}{l}\text { On poll tax } \\
\text { principle }\end{array}$ & & $\begin{array}{l}\text { Free choice } \\
\text { of a doctor by } \\
\text { a patient on a long } \\
\text { duration basis }\end{array}$ \\
\hline $\begin{array}{l}\text { France } \\
{[5]}\end{array}$ & General practitioners & Private practicing doctors & $\begin{array}{l}\text { Under primary link doctors' } \\
\text { referral ('goalkeeper' } \\
\text { principle); } \\
\text { possible independent access } \\
\text { to specialists of the patients } \\
\text { at their own expense with } \\
\text { payment up to } 40 \% \text { of such } \\
\text { service cost }\end{array}$ & & & $\begin{array}{l}\text { Free choice } \\
\text { of a doctor by } \\
\text { a patient on a long } \\
\text { duration basis }\end{array}$ \\
\hline $\begin{array}{l}\text { Canada } \\
{[7]}\end{array}$ & General practitioners & $\begin{array}{l}\text { 1. Private practicing doctors; } \\
\text { 2. Municipal first aid health } \\
\text { centres have been spread } \\
\text { lately }\end{array}$ & $\begin{array}{l}\text { Under primary link doctors' } \\
\text { referral (goalkeeper principle) }\end{array}$ & Fee & $\begin{array}{l}\text { On the primary level } \\
\text { mother and child } \\
\text { health is not considered } \\
\text { separately from other } \\
\text { medical services }\end{array}$ & $\begin{array}{l}\text { Free choice } \\
\text { of a doctor by } \\
\text { a patient on a long } \\
\text { duration basis }\end{array}$ \\
\hline $\begin{array}{l}\text { Denmark } \\
\text { [4] }\end{array}$ & General practitioners & $\begin{array}{l}\text { 1. Group practice of private } \\
\text { practicing doctors; } 2 \text {. } \\
\text { Individual practice comprises } \\
\text { nearly one-third of } \mathrm{PHC} \\
\text { structures }\end{array}$ & $\begin{array}{l}\text { Under primary link doctors' } \\
\text { referral ('goalkeeper' } \\
\text { principle) }\end{array}$ & $\begin{array}{l}\text { Mixed: poll tax } \\
\text { principle+fee }\end{array}$ & $\begin{array}{l}\text { On the primary level, } \\
\text { mother and child health } \\
\text { is not treated separately } \\
\text { from other medical } \\
\text { services }\end{array}$ & $\begin{array}{l}\text { Free choice } \\
\text { of a doctor by } \\
\text { a patient on a long } \\
\text { duration basis }\end{array}$ \\
\hline $\begin{array}{l}\text { United } \\
\text { Kingdom } \\
{[12]}\end{array}$ & $\begin{array}{l}\text { General practitioners; } \\
\text { dentists; } \\
\text { opticians; } \\
\text { pharmacists. }\end{array}$ & $\begin{array}{l}\text { 1. Trusts primary health care } \\
\text { centres ( } 151), \text { most }(71 \%) \\
\text { general practitioners are in } \\
\text { contractual relations with } \\
\text { them; } \\
\text { 2. Group practice }\end{array}$ & $\begin{array}{l}\text { Under primary link doctors' } \\
\text { referral (goalkeeper principle) }\end{array}$ & $\begin{array}{l}\text { On poll tax } \\
\text { principle }\end{array}$ & $\begin{array}{l}\text { On the primary level } \\
\text { mother and child } \\
\text { health is not considered } \\
\text { separately from other } \\
\text { medical services }\end{array}$ & $\begin{array}{l}\text { Free choice } \\
\text { of a doctor by } \\
\text { a patient on a long } \\
\text { duration basis }\end{array}$ \\
\hline $\begin{array}{l}\text { Germany* } \\
\text { [3] }\end{array}$ & $\begin{array}{l}\text { General practitioners; } \\
\text { physicians and } \\
\text { pediatricians }\end{array}$ & $\begin{array}{l}\text { Private practice (individual } \\
\text { or group) }\end{array}$ & $\begin{array}{l}\text { Access to specialists is not } \\
\text { regulated; patients can } \\
\text { address any specialist; access } \\
\text { with general practitioners' } \\
\text { referral is being introduced }\end{array}$ & $\begin{array}{l}\text { For a service; } \\
\text { the measures } \\
\text { to use poll tax } \\
\text { principle are being } \\
\text { taken }\end{array}$ & & $\begin{array}{l}\text { Free choice } \\
\text { of a doctor by } \\
\text { a patient on a long } \\
\text { duration basis }\end{array}$ \\
\hline
\end{tabular}

* Special feature of PHC structure in Germany in comparison with other countries results from the influence of historic development of health care system in the country

- a system of motivation of medical institutions and staff for intensive and high-quality work is created: the amount of financing of institutions of PHC, starting in 2013, will depend on the number of people attached, and the salary of medical staff - on the number of people served, and achievement of the planned indices of the quality of work;

- from 1 January 2013, it is planned that patients will be served by PHC physicians selected by the patients (attachment to doctors is scheduled from 1 January - 30 September 2012), which will promote the formation of a partnership between doctor and patient, on the one hand, and competition between doctors in their struggle for the patient;
- the system of forming patients' rational routes is renewed by using patient referral by the PHC physician when it is necessary to receive specialized and highly specialized medical care. It should be noted that in cases of emergency, when consulting an obstetrician-gynecologist, dentist, or paediatrician, when patients suffering from chronic diseases need regular medical check-ups under specialized medical care, this can be provided without any referral). 


\section{CONCLUSIONS}

Thus, the modernization of PHC that has been launched cannot improve health indices immediately. However, it lays the solid foundation for its strengthening and creates the basis for the formation of fundamentally new mutual relations between doctors and patients, when doctors will be interested in meeting people's needs in medical care, and patients will start confiding in their physician the most precious thing they possess - their health.

The perspectives of research are connected with the further study of issues of modernization of $\mathrm{PHC}$ for the population of Ukraine, taking into account international experience.

\section{REFERENCES}

1.Атун Р. Каковы преимущества и недостатки реструктуризации системы здравоохранения в целях большей ее ориентации на службы первичной медико-санитарной помощи? http://www.euro. who.int/document/e82997R.pdf (dostęp: 2013.10.10).

2. An Avoidable Tragedy: Combating Ukraine's health crisis, Lessons from Europe. Health and Demography Series. World Bank Publishers; 2009.
3. Busse R. Health care systems in transition: Germany. WHO Regional Office for Europe on behalf of the European Observatory on Health Systems and Policies Publishers; 2004.

4. Olejaz M, Nielsen AJ, Rudkjwbing A, et al. Denmark: Health system review. Health Systems in Transition. 2012; 14(2): 1-192.

5. Chevreul K, Durand-Zaleski I, Bahrami S, et al. France: Health system review. Health Systems in Transition. 2010; 12(6): 1-291.

6. Macinko J, Starfield B. The Impact of Primary Healthcare on Population Health in Low- and Middle-Income Countries. Journal Ambulatory Care Manage (JACM). 2009; 2: 150-171.

7. Marchildon GP. Health Systems in Transition: Canada. WHO Regional Office for Europe on behalf of the European Observatory on Health Systems and Policies Publishers; 2005.

8. Atun R, Richardson E, Shishkin S, et al. Moldova: Health system review. Health Systems in Transition. 2008; 10(5): 1-138.

9. Sagan A, Panteli D, Borkowski W, et al. Poland: Health system review. Health Systems in Transition. 2011; 13(8): 1-193.

10. Primary Health Care now more than ever: the world health report. Geneva: WHO, 2008. - 125 p.

11. Rosen B, Merkur S. Israel: Health system review. Health Systems in Transition. 2009; 11(2): 1-226.

12.Segn B. United Kingdom (England): Health system review. Health Systems in Transition. 2011; 13(1): 1-486.

13. Macinko J, Starfield B. The Impact of Primary Healthcare on Population Health in Low- and Middle-Income Countries / J. Macinko // Journal Ambulatory Care Manage. (JACM). 2009; 32 (2): 150-171.

14. Shi L. The Impact of Primary Care: A Focused Review. http://dx.doi. org/10.6064/2012/432892 (dostęp: 2013.10.10).

\section{Rozwój podstawowej opieki zdrowotnej na Ukrainie w świetle trendów światowych}

\section{Streszczenie}

Wprowadzenie i cel badań. W pracy przeanalizowano różne podejścia, zasady i wymagania dotyczące organizacji podstawowej opieki zdrowotnej (POZ), których efektywność została potwierdzona dobrze zaplanowanymi badaniami prowadzonymi na świecie. Celem artykułu jest ocena zgodności podejścia do poprawy systemu świadczenia POZ na Ukrainie z rzeczywistymi standardami międzynarodowymi.

Materiały i metody. Przeprowadzono analizę porównawczą organizacji POZ w różnych krajach europejskich. Stwierdzono, że model poprawy opieki zdrowotnej na Ukrainie jest w pełni zgodny z zasadami, wymaganiami i kryteriami skutecznego funkcjonowania POZ na świecie.

Wyniki. Co więcej, w oparciu o bieżące dane, określono zespół środków związanych z wdrażaniem modelu poprawy POZ na Ukrainie.

\section{Słowa kluczowe}

podstawowa opieka zdrowotna, model, składowe, poprawa 